\begin{tabular}{cc}
\hline & COMPUTATIONAL RESEARCH PROGRESS IN APPLIED SCIENCE \& ENGINEERING (CRPASE) \\
\end{tabular}

\title{
An Interval Type-2 Fuzzy Analytic Network Process For Prioritizing of Store Plan Alternatives Produced With Ruled Based Design
}

\author{
Sahika Ozdemir ${ }^{1 *}$, Kemal Gokhan Nalbant ${ }^{2}$, Yavuz Ozdemir ${ }^{3}$ \\ ${ }^{1}$ Department of Interior Architecture and Environmental Design, Istanbul Sabahattin Zaim University, Istanbul, Turkey \\ ${ }^{2}$ Department of Software Engineering, Beykent University, Istanbul, Turkey \\ ${ }^{3}$ Department of Industrial Engineering, Istanbul Health and Technology University, Istanbul, Turkey
}

\begin{tabular}{ll}
\hline Keywords & Abstract \\
\cline { 2 - 3 } $\begin{array}{l}\text { Computer-aided design, } \\
\text { Ruled based design, }\end{array}$ & $\begin{array}{l}\text { The widespread use of computer technologies in engineering and architecture provides } \\
\text { Fuzzy logic, }\end{array}$ \\
$\begin{array}{l}\text { Interval Type-2 Fuzzy } \\
\text { ANP, }\end{array}$ & $\begin{array}{l}\text { computational design approach, which emerged depending on computer science and design } \\
\text { theories and software and hardware technologies, is reflected in today's engineering and } \\
\text { architectural works. In this study, store plan alternatives were prioritized by the Interval }\end{array}$ \\
$\begin{array}{l}\text { Type-2 Fuzzy Analytic Network (IT2 FANP) methodology, and the best alternative of store } \\
\text { plans was selected. In addition, the results obtained for the four methods were compared. } \\
\text { Type-2 Fuzzy Set can reduce the effects of vagueness and uncertainties. These sets make it } \\
\text { probable to model uncertainties directly. There are very few studies on the IT2 FANP } \\
\text { method for architectural design area in the literature. Our aim is to contribute to the literature } \\
\text { by increasing the studies in this field. }\end{array}$ \\
\hline
\end{tabular}

\section{Introduction}

Spaces are shaped according to the determined principles and gain meaning according to human needs. Depending on these requirements, spaces with different functions were needed for various actions.

In addition to receiving the necessary needs in the history of mankind, shopping can be described as a relaxation, arousal and social act. Therefore, the designs of the stores which have shopping venues have gained great importance.

According to Novak's definition, the store design is the architectural character or style of that store, which tells customers what the store is about [1]. The design of the stores is very diverse in terms of variety, scale and geographical location. Large and very high stores can have negative effects on some customers, such as shyness or intimidation. In order to eliminate this shyness of customers, some floors of multi-storey stores are built underground [2]. Store design should be designed in such a way as to have a positive impact on customers, as well as to make retailing activities more economical.

Interior and facade design has an important place in the design of the store, which is a shopping area. While designing the interior of the store, firstly, the product sold and the quality of the product are determined [3].

Store plan alternatives were prioritized by Fuzzy Analytical Hierarchy Process (FAHP), Fuzzy Analytic Network Process (FANP) and Generalized Choquet Integral methods in the previous studies [4], [5]. In this paper, we applied an IT2 FANP technique to choose the best alternative of store plan.

Multiple-Criteria Decision-Making (MCDM) methodologies are very important for decision-making problems. Many decision-making problems are solved by

* Corresponding Author: Sahika Ozdemir

E-mail address: sahika.ozdemir@izu.edu.tr

Received: 19 December 2021; Revised: 26 December 2021; Accepted: 28 December 2021

https://doi.org/10.52547/crpase.7.4.2417

Academic Editor: Muhammad Ammar Khan

Please cite this article as: S. Ozdemir, K. Gokhan Nalbant, Y. Ozdemir, An Interval Type-2 Fuzzy Analytic Network Process For Prioritizing of Store Plan Alternatives Produced With Ruled Based Design, Computational Research Progress in Applied Science \& Engineering, CRPASE: Transactions of Applied Sciences 7 (2021) 1-5, Article ID: 2417. 
MCDM methodologies. There are many studies in the literature using MCDM methodologies [6];[14].

The FANP methodology is used to solve MCDM problems. Many researchers have studied FANP. Mohanty et al. [15] used a FANP in selecting research and development projects. Guneri et al. [16] used a FANP approach for shipyard location selection. Kang et al. [17] proposed a FANP model to evaluate various aspects of suppliers. Dargi et al. [18] developed a framework for supplier selection. Rezaeiniya et al. [19] used FANP methodology for greenhouse locating.

Interval Type-2 Fuzzy Set (IT2 FS) is an especial version of generalized Type-2 Fuzzy Set (T2 FS). Karnik, Mendel and Liang [20], Mendel, John and Liu [21], Chen and Lee [22], Sola et al. [23] and Boran and Akay [24] have contributed to developing IT2 FSs.

The FANP methodology with Interval Type-2 Fuzzy Sets (IT2 FSs) is used to solve MCDM problems. Senturk et al. [25] aimed to propose a new FANP method using IT2 FSs. Wu and Liu [26] developed a FANP methodology with IT2 FSs to evaluate the Enterprise Technology Innovation Ability (ETIA). Senturk et al. [27] found a new IT2 FANP methodology to model a Third-party Logistics (3PL) company selection problem by integrating ANP and IT2 FSs.

In the second section, an IT2 FANP method for prioritizing store plan alternatives is made. Finally, the "Conclusion" section concludes the article discusses the comparison of outcomes and future research directions. This document provides required guidelines for the authors to prepare their English papers by an identical standard format acceptable to this journal. The fulfillment of these instructions is mandatory for all contributors.

\section{An IT2 FANP Application: Prioritization of Plan Alternatives}

In this study, IT2 FANP methodology was used with the same data as previous studies [4], [5]. The outcomes are compared with the previous studies. In this section, we apply the IT2 FANP technique, which was found for choosing the best store plan alternative [25]. Decision criteria and alternatives for the problem were determined by the decision-makers in Figure 1. 8 sub-criteria were categorized under 3 main criteria and shown in Table 1.

Table 1. Criteria of problem

\begin{tabular}{|c|c|c|c|}
\hline & Main Criteria & & Sub-criteria \\
\hline \multirow{3}{*}{$\mathrm{C} 1$} & \multirow{3}{*}{$\begin{array}{c}\text { Store Presentation Area } \\
\text { Features }\end{array}$} & C11 & \multirow{3}{*}{$\begin{array}{c}\text { Facade/Showcase } \\
\text { Interior Layout } \\
\text { Entrance }\end{array}$} \\
\hline & & C12 & \\
\hline & & $\mathrm{C} 13$ & \\
\hline \multirow{3}{*}{$\mathrm{C} 2$} & \multirow{3}{*}{ Store Retail Area Features } & $\mathrm{C} 21$ & Retail Area Position \\
\hline & & $\mathrm{C} 22$ & Security \\
\hline & & $\mathrm{C} 23$ & Circulation \\
\hline \multirow[b]{2}{*}{ C3 } & \multirow{2}{*}{$\begin{array}{l}\text { Store-Customer } \\
\text { Relationship }\end{array}$} & C31 & Customer Pleasure \\
\hline & & $\mathrm{C} 32$ & $\begin{array}{l}\text { Items That Meet The } \\
\text { Customer First }\end{array}$ \\
\hline
\end{tabular}

The plan alternatives are $\mathrm{A} 1, \mathrm{~A} 2$, and $\mathrm{A} 3$, as seen in Figure 1. These are given in Figures 2, 3, 4. All characters used in the Figures are explained in Table 2 [28].
Table 2. Character explanation

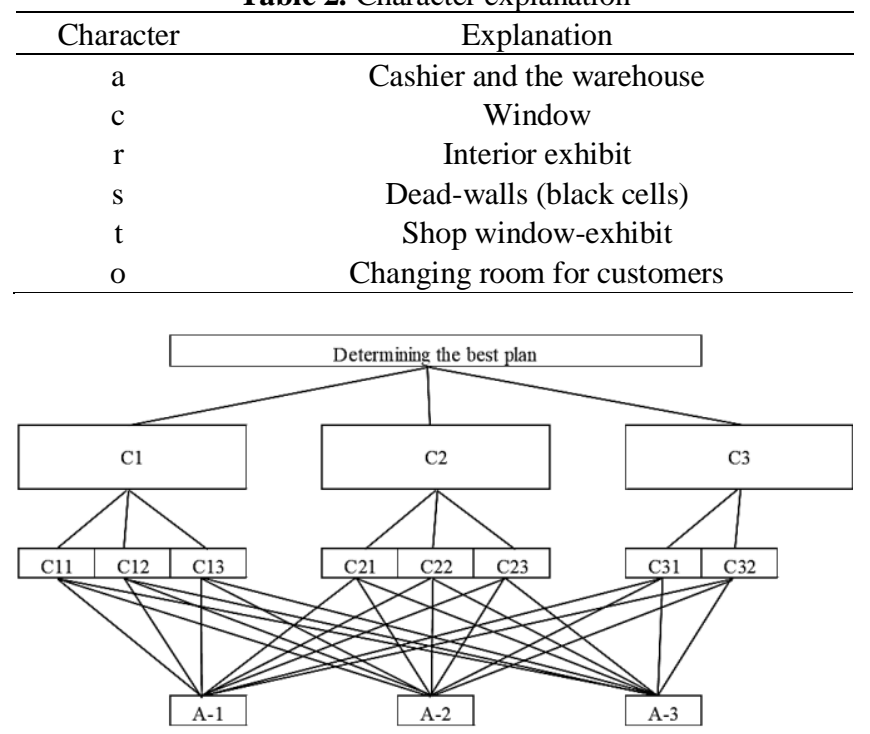

Figure 1. Hierarchy of the selection problem

At the same time as growing the model [28], the present shop typologies have been examined by considering the dominated-based design precept. The main spatial aspects of the shop have been emphasized in the scope of the performance (Figure 2, 3 and 4).

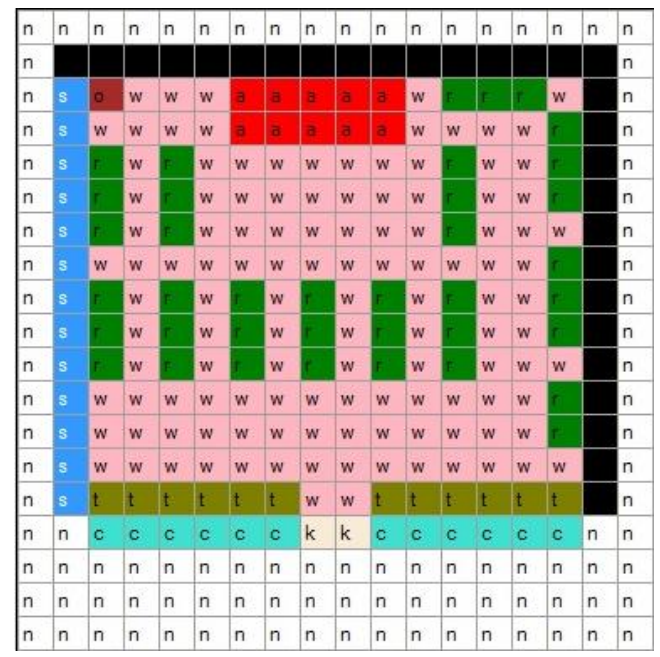

Figure 2. Alternative-1 [28]

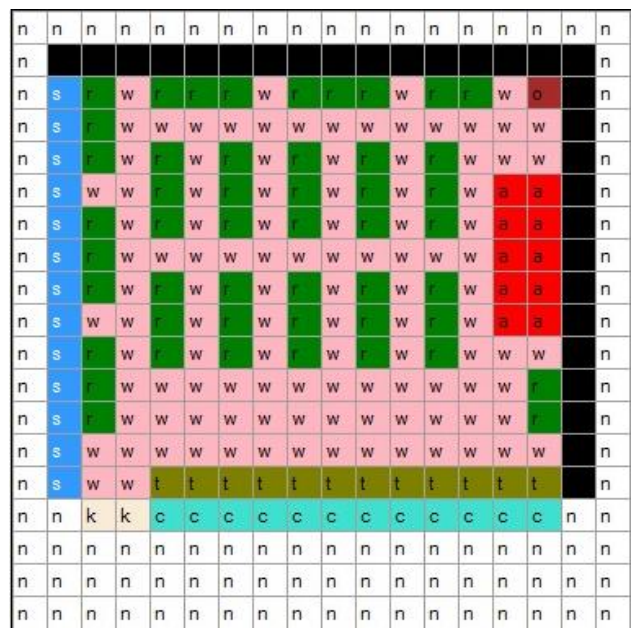

Figure 3. Alternative-2 [28] 


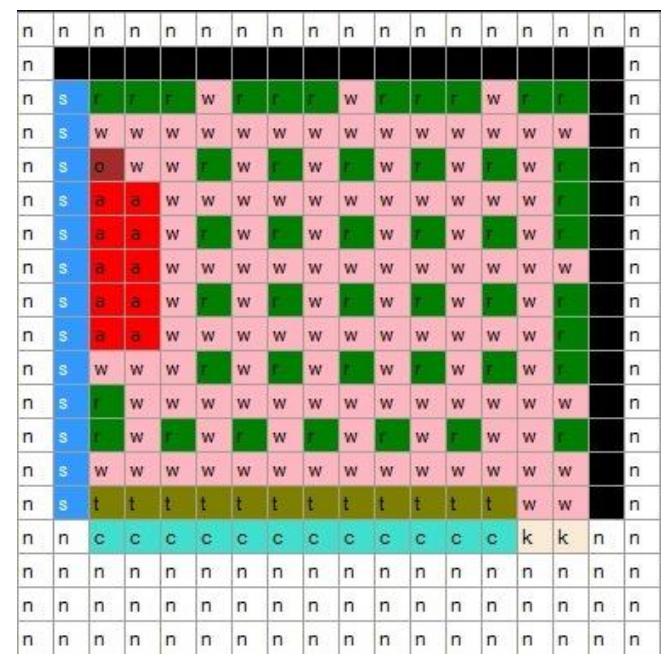

Figure 4. Alternative-2 [28]

IT2 fuzzy scales can be seen in Table 3 [29]. Also, these terms can be used in IT2 FANP.

The geometric mean of criteria (main, sub) is calculated. Then fuzzy weights for criteria (main, sub) are obtained [26]. Alternatives' local weights are found and their fuzzy weights are aggregated in Table 6.
Table 3. IT2 fuzzy scales

\begin{tabular}{|c|c|c|}
\hline $\begin{array}{c}\text { Low/ } \\
\text { high Levels }\end{array}$ & $\begin{array}{l}\text { Linguistic } \\
\text { Terms }\end{array}$ & Trapezoidal IT2 fuzzy scales \\
\hline 0 & $\begin{array}{l}\text { Fairly } \\
\text { Strong }\end{array}$ & $(3,4,6,7 ; 1,1)(3.2,4.2,5.8,6.8 ; 0.8,0.8)$ \\
\hline $\mathrm{E}$ & $\begin{array}{l}\text { Exactly } \\
\text { Equal }\end{array}$ & $(1,1,1,1 ; 1,1)(1,1,1,1 ; 1,1)$ \\
\hline A & $\begin{array}{l}\text { Absolutely } \\
\text { Strong }\end{array}$ & $(7,8,9,9 ; 1,1)(7.2,8.2,8.8,9 ; 0.8,0.8)$ \\
\hline S & $\begin{array}{l}\text { Slightly } \\
\text { Strong }\end{array}$ & $(1,2,4,5 ; 1,1)(1.2,2.2,3.8,4.8 ; 0.8,0.8)$ \\
\hline $\mathrm{V}$ & $\begin{array}{l}\text { Very } \\
\text { Strong }\end{array}$ & $(5,6,8,9 ; 1,1)(5.2,6.2,7.8,8.8 ; 0.8,0.8)$ \\
\hline
\end{tabular}

Comparisons are made to solve the problem using IT2 FANP methodology by decision-makers. The fuzzy pairwise comparison matrix (Fpcm) between main and sub-criteria are shown in Table 4 and Table 5. Dma, Dmb, and Dmc denote the comparisons of decision-maker-A, decision-maker-B, and decision-maker- $\mathrm{C}$ in these tables.

Table 4. Fpcm among main criteria

\begin{tabular}{cccccccccc}
\hline & \multicolumn{1}{c}{$\mathrm{C} 1$} & \multicolumn{4}{c}{$\mathrm{C} 2$} & \multicolumn{3}{c}{$\mathrm{C} 3$} \\
\hline & Dma & Dmb & Dmc & Dma & Dmb & Dmc & Dma & Dmb & Dmc \\
$\mathrm{C} 1$ & $\mathrm{E}$ & $\mathrm{E}$ & $\mathrm{E}$ & $\mathrm{E}$ & $\mathrm{E}$ & $\mathrm{E}$ & $\mathrm{E}$ & $\mathrm{S}$ & $\mathrm{E}$ \\
$\mathrm{C} 2$ & $\mathrm{E}$ & $\mathrm{E}$ & $\mathrm{E}$ & $\mathrm{E}$ & $\mathrm{E}$ & $\mathrm{E}$ & $\mathrm{E}$ & $\mathrm{S}$ & $\mathrm{E}$ \\
$\mathrm{C} 3$ & $\mathrm{E}$ & $1 / \mathrm{S}$ & $\mathrm{E}$ & $\mathrm{E}$ & $1 / \mathrm{S}$ & $\mathrm{E}$ & $\mathrm{E}$ & $\mathrm{E}$ & $\mathrm{E}$ \\
\hline
\end{tabular}

Table 5. Fpcm among sub-criteria

\begin{tabular}{|c|c|c|c|c|c|c|c|c|c|c|c|c|c|c|c|c|c|c|c|c|c|c|c|c|}
\hline & & $\mathrm{C} 11$ & & & $\mathrm{C} 12$ & & & C13 & & & $\mathrm{C} 21$ & & & $\mathrm{C} 22$ & & & $\mathrm{C} 23$ & & & C31 & & & C32 & \\
\hline & $\mathrm{Dm}$ & $\mathrm{Dmb}$ & Dmc & $\mathrm{Dm}$ & Dmb & Dmc & Dms & Dmb & Dmc & Dma & $\mathrm{Dmb}$ & Dmc & Dma & $\mathrm{Dmb}$ & $\mathrm{bDmc}$ & Dma & Dmb & Dmc & Dma & $\mathrm{aDmb}$ & Dmc & Dma & Dmb & Dmc \\
\hline C11 & E & $\mathrm{E}$ & $\mathrm{E}$ & $\mathrm{E}$ & S & $1 / \mathrm{S}$ & $\mathrm{E}$ & $S$ & $1 / \mathrm{S}$ & E & $\mathrm{E}$ & E & $\mathrm{E}$ & $\mathrm{E}$ & S & E & $\mathrm{E}$ & E & $\mathrm{E}$ & S & $1 / \mathrm{S}$ & $\mathrm{E}$ & $\mathrm{E}$ & V \\
\hline $\mathrm{C} 12$ & $\mathrm{E}$ & $1 / \mathrm{S}$ & $S$ & $\mathrm{E}$ & E & $\mathrm{E}$ & E & $\mathrm{E}$ & $\mathrm{E}$ & $\mathrm{E}$ & $1 / \mathrm{S}$ & $S$ & E & $1 / \mathrm{S}$ & $\mathrm{F}$ & $\mathrm{E}$ & $1 / \mathrm{S}$ & $S$ & E & $\mathrm{E}$ & $\mathrm{E}$ & E & $1 / \mathrm{S}$ & V \\
\hline $\mathrm{C} 13$ & $\mathrm{E}$ & $1 / \mathrm{S}$ & $S$ & $\mathrm{E}$ & E & $\mathrm{E}$ & $\mathrm{E}$ & $\mathrm{E}$ & $\mathrm{E}$ & E & $1 / \mathrm{S}$ & $S$ & E & $1 / \mathrm{S}$ & $\mathrm{F}$ & $\mathrm{E}$ & $1 / \mathrm{S}$ & $\mathrm{S}$ & E & E & $\mathrm{E}$ & E & $1 / \mathrm{S}$ & V \\
\hline $\mathrm{C} 21$ & E & $\mathrm{E}$ & $\mathrm{E}$ & E & $S$ & $1 / \mathrm{S}$ & $\mathrm{E}$ & $S$ & $1 / \mathrm{S}$ & E & $\mathrm{E}$ & $\mathrm{E}$ & E & $\mathrm{E}$ & $S$ & E & $\mathrm{E}$ & E & E & $S$ & $1 / \mathrm{S}$ & E & $\mathrm{E}$ & $\mathrm{F}$ \\
\hline $\mathrm{C} 22$ & E & E & $1 / \mathrm{S}$ & E & $S$ & $1 / \mathrm{F}$ & E & $S$ & $1 / \mathrm{F}$ & E & E & $1 / \mathrm{S}$ & E & E & E & E & E & $1 / \mathrm{S}$ & E & $S$ & $1 / F$ & E & E & $\mathrm{F}$ \\
\hline C23 & E & $\mathrm{E}$ & $\mathrm{E}$ & E & $\mathrm{S}$ & $1 / \mathrm{S}$ & E & $S$ & $1 / \mathrm{S}$ & E & E & $\mathrm{E}$ & E & E & $\mathrm{S}$ & E & E & $\mathrm{E}$ & E & $\mathrm{S}$ & $1 / \mathrm{S}$ & E & E & $\mathrm{F}$ \\
\hline C31 & E & $1 / \mathrm{S}$ & $\mathrm{S}$ & E & E & E & E & E & $\mathrm{E}$ & E & $1 / \mathrm{S}$ & $S$ & E & $1 / \mathrm{S}$ & $\mathrm{F}$ & E & $1 / \mathrm{S}$ & $\mathrm{S}$ & E & E & $\mathrm{E}$ & E & $1 / \mathrm{S}$ & V \\
\hline C32 & E & $\mathrm{E}$ & $1 / \mathrm{V}$ & E & $\mathrm{S}$ & $1 / \mathrm{V}$ & E & $\mathrm{S}$ & $1 / \mathrm{V}$ & E & $\mathrm{E}$ & $1 / \mathrm{F}$ & E & E & $1 / \mathrm{F}$ & E & $\mathrm{E}$ & $1 / \mathrm{F}$ & E & $\mathrm{S}$ & $1 / \mathrm{V}$ & E & $\mathrm{E}$ & E \\
\hline
\end{tabular}

Table 6. Alternatives' fuzzy weights

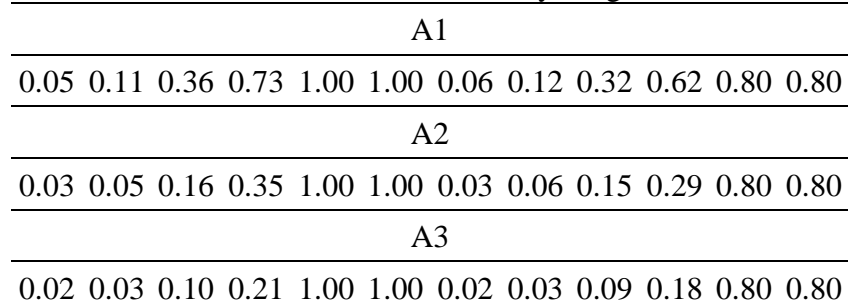

Then, Type-2 fuzzy numbers are defuzzified using Defuzzification of trapezoidal Type-2 fuzzy sets (DTraT) method, as seen in Table 6 .
Table 7. Outcomes of the application using IT2 FANP methodology

\begin{tabular}{lcc}
\hline & Fuzzy weights & Normalized values \\
\hline A1 & 0.284 & $56.80 \%$ \\
A2 & 0.135 & $27.00 \%$ \\
A3 & 0.081 & $16.20 \%$ \\
\hline
\end{tabular}

Fuzzy weights are found as $0.284,0.135$, and 0.081 in Table 7. So, the ranking is found as "A1>A2>A3". The comparison of the outcomes with FAHP, FANP and Choquet integral methods is shown in Table 8. When the outcomes are analyzed for all methods, the ranking is found as "A1>A2>A3". Furthermore, it would be said that choosing A1 is the most relevant result. 
Table 8. Comparison of the outcomes with FAHP, FANP and Choquet integral

\begin{tabular}{|c|c|c|c|c|c|c|c|c|}
\hline & \multicolumn{4}{|c|}{ Weights } & \multicolumn{4}{|c|}{ Normalized Values } \\
\hline & $\begin{array}{c}\text { IT2 } \\
\text { FANP }\end{array}$ & $\begin{array}{l}\text { Choquet } \\
\text { integral }\end{array}$ & FAHP & FANP & $\begin{array}{c}\text { IT2 } \\
\text { FANP }\end{array}$ & $\begin{array}{l}\text { Choquet } \\
\text { integral }\end{array}$ & FAHP & FANP \\
\hline A1 & 0.284 & 1.1339 & 2.3766 & 1.0000 & $56.80 \%$ & $45.87 \%$ & $69.34 \%$ & $65.23 \%$ \\
\hline $\mathrm{A} 2$ & 0.135 & 0.8987 & 0.7892 & 0.3548 & $27.00 \%$ & $36.35 \%$ & $23.02 \%$ & $23.14 \%$ \\
\hline A3 & 0.081 & 0.4396 & 0.2618 & 0.1782 & $16.20 \%$ & $17.78 \%$ & $7.64 \%$ & $11.62 \%$ \\
\hline
\end{tabular}

\section{Conclusions}

These days, many different application regions of ruledbased design are encountered. The improvement in laptop generation presents an advantage to designers at tiers, including developing different layout strategies using ruleprimarily based facilities.

In this study, Type-2 Fuzzy Analytic Network (IT2 FANP) methodology was compared with FAHP, FANP and Choquet integral methods.

Consequently, using the IT2 fuzzy scales, this methodology has obtained the most appropriate outcome as $\mathrm{A} 1$ and ranking as "A1>A2>A3". When the results are analyzed, the alternative's ranking is "A1 $>\mathrm{A} 2>\mathrm{A} 3$ " for all methods with normalized values and different weights.

Concerning future research, the problem can be evaluated with other MCDM methods, and more hybrid/integrated solutions can be studied for the evaluation processes of store plan alternatives. In addition, intelligent software can be developed to automatically calculate solutions to these problems.

\section{Conflict of Interest Statement}

The authors declare that they have no conflicts of interest/competing interests.

\section{References}

[1] L. Novak, Store Planning and Design. Friedman Books, New York, 1977.

[2] F. Demirci, Store arrangement in retail. Beta Publishing, Istanbul, 2000.

[3] S. Ertas, Analysis of spatial units shopping store in Turkey. Master Thesis, Karadeniz Technical University, Graduate School of Natural and Applied Sciences, Trabzon, 2006.

[4] S. Ozdemir and Y. Ozdemir, Prioritizing store plan alternatives produced with shape grammar using multicriteria decision-making techniques, Environment and Planning B: Urban Analytics and City Science 45 (2018) 751-771.

[5] Y. Ozdemir and S. Ozdemir, Extended prioritizing of store plan alternatives produced with shape grammar using the generalized Choquet integral method, Environment and Planning B: Urban Analytics and City Science 46 (2019) 931-947.

[6] Y. Ozdemir, K. G. Nalbant and H. Basligil, Evaluation of personnel selection criteria using Consistent Fuzzy Preference Relations, International Journal of Management Science, 4 (2017) 76-81.

[7] Y. Ozdemir, K. G. Nalbant and H. Basligil, Personnel selection for promotion using an integrated fuzzy analytic hierarchy process-Grey relational analysis methodology: A real case study, Anadolu Üniversitesi Bilim ve Teknoloji Dergisi A-Uygulamalı Bilimler ve Mühendislik 19 (2018) 278-292.
[8] Y. Ozdemir and K. G. Nalbant, A Real Personnel Selection Problem Using The Generalized Choquet Integral Methodology, Business \& Management Studies: An International Journal 6 (2018) 694-716.

[9] K. G. Nalbant and Y. Ozdemir, Personnel Selection Using Fuzzy VIKOR Methodology, International Journal of Management Science 5 (2018) 10-17.

[10] Y. Ozdemir and K. G. Nalbant, Personnel selection for promotion using an integrated consistent fuzzy preference relations-fuzzy analytic hierarchy process methodology: A real case study, Asian Journal of Interdisciplinary Research 3 (2020) 219-236.

[11] S. Ozdemir, K.G. Nalbant and Y. Ozdemir, Evaluating Campus Components According To The Inclusive Design Principles Using An Integrated Consistent Fuzzy Preference Relations And Grey Relational Analysis Methodology, Computational Research Progress in Applied Science \& Engineering, CRPASE: Transactions of Civil and Environmental Engineering 7 (2021) 1-5.

[12] K. G. Nalbant, S. Ozdemir and Y. Ozdemir, Evaluating Inclusive Campus Environment Design Criteria Using CFPR and FANP Methodologies, WSEAS Transactions on Computer Research 9 (2021) 92-102.

[13] S. Nasehi, S. Karimi, S. and H. Jafari, Application of fuzzy GIS and ANP for wind power plant site selection in East Azerbaijan Province of Iran, Computational Research Progress in Applied Science \& Engineering 2 (2016) 116124.

[14] M. Khaksar, M. Malakoutian, V. Najafi, M. Gilani, and R. Salehfard, Analysis of Natural Gas Transportation Prices from Cyprus to Turkey, Computational Research Progress in Applied Science \& Engineering (2021).

[15] R.P. Mohanty, R. Agarwal, A.K. Choudhury and M.K. Tiwari, A fuzzy ANP-based approach to R\&D project selection: A case study, International Journal of Production Research 43 (2005) 5199-5216.

[16] A.F. Guneri, M. Cengiz, and S. Seker, A fuzzy ANP approach to shipyard location selection, Expert Systems with Applications 36 (2009) 7992-7999.

[17] H.Y. Kang, A.H. Lee and C.Y. Yang, (2012) A fuzzy ANP model for supplier selection as applied to IC packaging, Journal of Intelligent Manufacturing 23 (2012) 1477-1488.

[18] A. Dargi, A. Anjomshoae, M.R. Galankashi, A. Memari, and M.B.M. Tap, Supplier selection: A fuzzy-ANP approach, Procedia Computer Science 31 (2014) 691-700.

[19] N. Rezaeiniya, A.S. Ghadikolaei, J. Mehri-Tekmeh and H.R. Rezaeiniya, Fuzzy ANP approach for new application: Greenhouse location selection; a case in Iran, Journal of mathematics and computer Science 8 (2014) 1-20.

[20] N.N. Karnik, J.M. Mendel and Q. Liang, Type-2 fuzzy logic systems, IEEE Transactions on Fuzzy Systems 7 (1999) 643658.

[21] J.M. Mendel, R.I. John and F. Liu, Interval type-2 fuzzy logic systems made simple, IEEE Transactions on Fuzzy Systems 14 (2006) 808-821.

[22] S.M. Chen and L.W. Lee, Fuzzy multiple attributes group decision-making based on the ranking values and the 
arithmetic operations of interval type- 2 fuzzy sets, Expert Systems With Applications 37 (2010) 824-833.

[23] H.B. Sola, J. Fernandez, H. Hagras, F. Herrera, M. Pagola and E. Barrenechea, Interval type-2 fuzzy sets are generalization of interval-valued fuzzy sets: Toward a wider view on their relationship, IEEE Transactions on Fuzzy Systems 23 (2014) 1876-1882.

[24] F.E. Boran and D. Akay, A generic method for the evaluation of interval type-2 fuzzy linguistic summaries, IEEE Transactions On Cybernetics 44 (2013) 1632-1645.

[25] S. Senturk, Y. Binici and N. Erginel, The theoretical structure of fuzzy analytic network process (FANP) with interval type2 fuzzy sets, IFAC-PapersOnLine 49 (2016) 1318-1322.

[26] T. Wu and X. Liu, An interval type-2 fuzzy ANP approach to evaluate enterprise technological innovation ability, Kybernetes 45 (2016) 1486-1500.

[27] S. Senturk, N. Erginel and Y. Binici, Interval Type-2 Fuzzy analytic network process for modelling a third-party logistics (3PL) company, Journal of Multiple-Valued Logic \& Soft Computing 28 (2017).

[28] S. Ozdemir, A model proposal for designing a shop using shape grammar. Master Thesis, Istanbul Technical University, Graduate School of Natural and Applied Sciences, Istanbul, 2014.

[29] C. Kahraman, B. Oztaysi, I.U. Sari and E. Turanoglu, Fuzzy analytic hierarchy process with interval type-2 fuzzy sets, Knowledge-Based Systems 59 (2014) 48-57. 